\title{
Peningkatkan Prestasi Belajar Siswa Mata Pelajaran IPA Materi Penyesuaian Hewan dengan Lingkungannya Melalui Metode Resitasi
}

\author{
Kasmiatin \\ Sekolah Dasar Negeri 2 Joho Kecamatan Pule Kabupaten Trenggalek \\ Email: kasmiatin@gmail.com
}

\begin{abstract}
Abstrak: Proses pembelajaran kelas V Sekolah Dasar Negeri 2 Joho Kecamatan Pule Kabupaten Trenggalek, masih mengunakan metode konvensional yaitu metode ceramah.Kondisi seperti ini tidak akan meningkatkan kemampuan siswa dalam memahami materi pelajaran khususnya mata pelajaran IPA. Akibatnya nilai hasil ulangann 80\% dari 23 siswa di bawah KKM .Metode Resitasi memberikan kebebasan belajar secara mandiri, merangsang siswa belajar, berperan mengembangkan kemandirian siswa, membuat siswa bergairah karena kegiatan belajar dilakukan dengan berbagai variasi, kebebasan berpikir, berpendapat, aktif dankreatif. Setelah metode resitasi diterapkan ada kenaikan. Ditunjukkan dari penelitian pembelajaran pada siklus I tingkat keberhasilan ketuntasan kelas sebesar 56,52\%. Sedangkan padasiklus II

keberhasilan ketuntasan kelas sebesar 95,65\%.
\end{abstract}

Tersedia Online di

http://journal.unublitar.ac.id/pendidi kan/index.php/Riset_Konseptual

\begin{tabular}{l}
\hline Sejarah Artikel \\
\hline Diterima pada : 09-10-2019 \\
Disetujui pada : 27-10-2019 \\
Dipublikasikan pada : 31-10-2019 \\
\hline
\end{tabular}

Kata Kunci:

Metode Resitasi, Peningkatan Prestasi Belajar

DOI:

htt1/doi.org/10.28926/riset_konseptual.v3i4. 148

\section{PENDAHULUAN}

Pendidikan secara praktis tidak dapat dipisahkan dengan nilai-nilai terutama yang menyangkut kuaitas kecerdasan, kerajinan, ketekunan dan nilai-nilai yang diperoleh siswa selama mengikuti pelajaran. Prestasi adalah hasil yang telah dicapai (dari yang telah dilakukan, dikerjakan), (Kamus Besar bahasa Indonesia, 1980: 700). Prestasi merupakan yang berhasil maksudnya prestasi diwujudkan dalam kecakapan seseorang, suatu kelompok, suatu bangsa, bukan propaganda kosong atau rencana yang tak terlaksana, (Adinegoro), 1987: 78). Berdasarkan pendapat ahli di atas dapat disimpulkan bahwa yang dimaksud prestasi adalah bukti keberhasilan yang telah dicapai oleh individu atau kelompok dalam melakukan kegiatan.

Dalam proses pendidikan di sekolah, kegiatan pembelajaran merupakan kegiatan yang paling pokok. Hal ini berhasil atau tidaknya tujuan pembelajaran banyak tergantung pada bagaimana proses pembelajaran dan cara belajar siswa.

Belajar merupakan salah satu faktor yang mempengaruhi dan berperan penting dalam pembentukan pribadi dan perilaku individu, Selain itu, belajar akan menambah wawasan pengetahuan seseorang. Menurut Oemar Hamalik ( 2008: 36), "belajar adalah modifikasi atau memperteguh kelakuan melalui pengalaman. (learning is defined as the modification or streng thening of behavior through experiencing). Jadi belajar merupakan suatu proses yang tidak hanya mengingat, akan tetapi lebih luas daripada itu, yakni "mengalami".

Menurut Chaplin (dalam Muhibbin Syah 2010: 88), membatasi belajar dengan dua macam rumusan.Rumusan yang pertama berbunyi “... aquastion of any relatively permanent change in behavior as a result of practice and experience". Belajar adalah perolehan ilmu yang dapat mengakibatkan perubahan tingkah laku yang relatif menetap sebagai akibat praktik dan pengalaman.Rumusan keduanya adalah "process 
of acquiring responses as a result of special practice". Belajar adalah suatu proses memperoleh respon-respon sebagai akibat adanya pelatihan khusus.

Menurut Wittig (dalam Muhibbin Syah 2010: 89), "belajar ialah perubahan tingkah laku yang relatif menetap yang terjadi dalam segala macam/keseluruhan tingkah laku suatu organisme sebagai hasil pengalaman".

"Secara kuantitatif belajar adalah kegiatan pengisian atau pengembangan kemampuan kognitif dengan fakta sebanyak-banyaknya. Sedangkan secara kualitatif belajar adalah proses memperoleh arti-arti dan pemahaman-pemahaman serta caracara menafsirkan dunia disekeliling siswa" (Muhibbin Syah 2010: 90).

Berdarkan berbagai definisi yang telah diutarakan diatas tadi, secara umum belajar merupakan proses perubahan tingkah laku sebagai akibat pengembangan kemampuan kognitif melalui tahapan-tahapan perubahan seluruh tingkah laku individu yang relatif menetap sebagai hasil pengalaman dan interaksi dengan lingkungan yang melibatkan proses kognitif. Jadi yang dimaksud prestasi belajar ialah sesuatu yang telah dicapai oleh siswa selama mengikuti proses belajar mengajar.

Upaya melakukan penelitian di bidang pendidikan menjadi tanggung jawab semua pihak, salah satunya yaitu guru. Sebagaimana dijelaskan oleh Oemar Hamalik (2008: 123) yang mengatakan bahwa "Guru bertanggung jawab melaksanakan kegiatan pendidikan di sekolah dalam arti memberikan bimbingan dan pengajaran kepada para siswa". Guru harus dapat melakukan suatu inovasi yang menyangkut tugasnya sebagai pendidik yang berkaitan dengan tugas mengajar siswa. Tugas utama guru adalah mewujudkan tujuan-tujuan pendidikan di sekolah dengan mengembangkan strategi belajar mengajar secara efektif.

Metode pembelajaran dalam Proses Belajar Mengajar (PBM) terkesan sangat kaku, kurang fleksibel, kurang demokratis, dan guru cenderung lebih dominan.Guru kelas mengajar menggunakan model konvensional yang monoton, aktivitas guru lebih dominan daripada siswa, akibatnya guru seringkali mengabaikan proses pembinaan tatanan nilai, sikap, dan tindakan, sehingga mata pelajaran IPA tidak dianggap sebagai mata pelajaran pembinaan yang menekankan pada pengetahuan dan pembangunan daya pikir tetapi lebih cenderung menjadi mata pelajaran yang jenuh dan membosankan.

Untuk menghadapi tersebut di atas, guru perlu menggunakan metode pembelajaran yang efektif dan efisien sebagai alternatif, yaitu metode pembelajaran yang diharapkan mampu melibatkan siswa dalam keseluruhan proses pembelajaran dan dapat melibatkan seluruh aspek, yaitu kognitif, afektif, dan psikomotorik siswa, serta secara fisik dan mental melibatkan semua pihak dalam pembelajaran sehingga siswa memiliki suatu kebebasan berpikir, berpendapat,aktif dan kreatif.

Metode Resitasi memberikan kebebasan anak untuk belajar secara mandiri, yang lebih merangsang siswa untuk untuk belajar lebih banyak, baik pada waktu di kelas maupun di luar kelas.Selain itu metode resitasi berperan mengembangkan kemandirian siswa yang diperlukan kehidupan kelak. Metode ini dapat membuat siswa bergairah dalam belajar karena kegiatan belajar dilakukan dengan berbagai variasi sehingga tidak membosankan.

Proses pembelajaran kelas V Sekolah Dasar Negeri 2 Joho Kecamatan Pule Kabupaten Trenggalek, masih mengunakan metode konvensional yaitu metode ceramah,sehingga Kegiatan Belajar Mengajar (KBM) menjadi monoton dan kurang menarik perhatian siswa. Kondisi seperti itu tidak akan meningkatkan kemampuan siswa dalam memahami mata pelajaran khususnya mata pelajaran IPA dalam hal ini materi yang diberikan adalah penyesuaian mahluk hidup dengan lingkungannya yang terdiri dari penyesuaian bentuk tubuh terhadap lingkungan, penyesuaian tingkah laku terhadap lingkungan. Akibatnya nilai hasil ulangan harian sebelum metode resitasi diterapkan 80\% dari 23 siswa kelas V Sekolah Dasar Negeri 2 Joho Kecamatan Pule Kabupaten Trenggalekmasih di bawah KKM (di bawah nilai 70). 


\section{METODE}

Metode yang digunakan adalah metode resitasi. Metode resitasi adalah metode yang berupa tugas yang diberikan oleh guru untuk dipelajari siswa dengan temannya atau dipelajari sendiri (Roestiyah N.K (2008: 133).

Metode resitasi di berikan untuk memperoleh pengetahuan dengan cara melaksanakan tugas dan juga dapat memperluas dan memperkaya pengetahuan serta ketrampilan siswa disekolah melalui kegiatan luar sekolah. Dalam percakapan seharihari metode ini dikenal dengan sebutan pekerjaan rumah, tetapi sebenarnya metode ini terdiri dari tiga fase, antara lain (1) pendidik memberi tugas. (2) anak didik melaksanakan tugas (belajar). (3) Siswa mempertanggung jawabkan apa yang telah dipelajari (resitasi).

Penerapan metode resitasi (tugas), bertujuan agar siswa dapat belajar bebas tapi bertanggung jawab, dan murid-murid akan berpengalaman, dan bisa mengetahui berbagai kesulitan. Dengan metode ini siswa mendapatkan kesempatan untuk saling membandingkan dengan hasil siswa yang lain, menarik anak didik agar belajar lebih baik, punya tanggung jawab dan berdiri sendiri.

Metode resitasi ini digunakan atau di berikan untuk merangsang anak agar tekun, rajin, dan giat belajar, sehingga pada pada saat kegiatan belajar mengajar mereka sudah siap.Selain itu metode ini diberikan karena dirasa bahan pelajaran terlalu banyak sementara waktu sedikit, dalam arti bahan banyak tapi waktu kurang seimbang.Agar bahan yang diberikan dapat sesui dengan waktu yang ada maka metode ini bisa diberikan. Metode resitasi (tugas) dapat berupa antara lain: menyusun laporan mengenai bahan bacaan atau menyusun berita, menjawab pertanyaan yang ada dalam buku, tugas lain yang dapat menujang keberhasilan siswa, dll

Dalam pelaksanaan metode resitasi harus sesuai dengan bahan ajar yang akan diberikan kepada siswa dan juga sesuai dengan tingkat usia, adapun langkah -langkah yang harus diperhatikan dalam pemberian tugasadalah : memberikan tugas yang cukup jelas dipahami siswa sehingga mereka tidak perlu bertanya-tanya lagi, mengontrol apakah tugas dikerjakan dengan baik, apakah dikerjakan oleh siswa sendiri atau oleh orang lain, mengevaluasi hasil siswa untuk menumbuhkembangkan semangat kerja, mempertimbangkan tujuan yang akan dicapai dengan tugas itu.

\section{Pentingnya Metode Resitasi meningkatkan Prestasi Belajar Penyesuaian Hewan dengan Lingkungannya}

1) Metode resitensi dalam pelaksanaannya dapat meningkatkan prestasi Belajar Penyesuaian Hewan dengan Lingkungannya karena : a) Tugas yang diberikan kepada siswa jelas, sehingga mereka dapat mengerti apayang harus dikerjakan, b) Tugas yang diberikan kepada siswa dengan memperlihatkan perbedaan individu masing-masing, c) Waktu untuk menyelesaikan tugas haruslah cukup, d) Kontrol atau pengawasan yang sistimatis atas tugas yang diberikan sehingga mendorong siswa untuk belajar dengan sungguh-sungguh,e) Tugas yang diberikan hedaklah mempertibangkan : menarik minat dan perhatian siswa, mendorong siswa untuk mencari mengalami dan menyampaikan, diusahahakan tugas bersifat praktis dan ilmiah, bahan pelajaran yang ditugaskan agar diambilkan dari hal-hal yang dikenal siswa.

\section{Subyek Penelitian}

Yang menjadi subyek penelitian Tindakan Kelas ini ialah siswa kelas V SDN 2 Joho Kecamatan Pule Kabupaten Trenggalek tahun ajaran 2014-2015 dengan jumlah subjek 23 siswa. Terdiri dari 11 anak laki-laki dan 12 anak perempuan. Domisili dan Kemampuan dari anak tersebut bersifat heterogen,ada yang jauh dari sekolah dan dekat, ada yang pandai dan ada yang kurang pandai.

\section{Waktu Penelitian}

Penelitian Tindakan Kelas dilaksanakans selama dua siklus. Siklus I 2 x 35 menit dan siklus II 2 × 35 menit. Penelitian siklus I dilakukan pada tanggal, 6 Oktober 
2014 , sedangkan siklus II tanggal, 13 Oktober 2014 . Jadi dilaksanakan selama 14 hari pada semester ganjil tahun pelajaran 2014-2015.

\section{Tempat Penelitian}

Tempat penelitian tindakan kelas ini bertempat di SDN 2 Joho Kecamatan

Pule Kabupaten Trenggalek Provinsi Jawa Timur.

\section{Prosedur Penelitian}

Penelitian ini merupakan penelitian tindakan kelas, penelitian pembelajaran dilaksanakan dilaksanakan dua siklus. Adapun prosedur penelitiannya sebagai berikut :

\section{Pelaksanaan Siklus I}

\section{Perencanaan}

Dalam perencanaan ini penulis melaksanakan sebagai berikut : merumuskan tujuan rencana penelitian kelas, membuat silabus, membuat rpp, membuat alat evaluasi membuat lembar pengamatan, membuat lembar kerja, menyiapkan alat pembelajaran, membuat lembar catatan penelitian membuat lembarwawancara.

2. Pelaksanaan penelitian meliputi: a ) Pembukaan : mengucapkan salam, berdoa, mengabsen, tanya jawab materi yang lalu, guru menyampaikan topic pembelajaran. b) Inti meliputi : : guru menjelaskan penyesuaian hewan dengan lingkungannya, guru memberi tugas ( retirasi ) kepada siswa untuk mengamati penyesuaian hewan terhadap lingkungannya, guru meyuruh siswa duduk dengan kelompoknya, siswa membahas tugas yang telah dikerjakan dengan kelompoknya, anggota kelompok menanggapi hasil kerja temannya, siswa menyimpulkan hasil tanggapan terhadap tugas temanya satu kelompok. c) Penutup. Guru dan siswa menyimpulkan bersama-sama materi pelajaran, evaluasi.

3. Analisis hasil pengamatan atau observasi

Tahap observasi dalam penelitian ini meliputi : Melakukan pengamatan terhadap siswa selama proses penelitian berlangsung, Melakukan pencatatan terhadap kejadian yang ada dalam kegiatan penelitian ini, mulai awal sampai akhir, Mengumpulkan hasil pengamatan kegiatan pembelajaran.

4. Refleksi

Pada tahap ini peneliti mengadakan refleksi pelaksanaan pembelajaran yang telah dilaksanakan.Hasil refleksi digunakan sebagai dasar untuk mengadakan penelitian dan meningkatkan mutu pendidikan.

\section{Pelaksanaan Siklus II}

1. Perencanaan

Dalam perencanaan ini penulis melaksanakan sebagai berikut : merumuskan tujuan rencana penelitian kelas, membuat silabus, membuat rpp, membuat alat evaluasi, membuat lembar pengamatan, membuat lembar kerja, menyiapkan alat pembelajaran, membuat lembar catatan penelitian, membuat lembarwawancara

2. Pelaksanaan penelitian meliputi : a) Pembukaan : mengcapkan salam, berdoa, mengabsen, tanya jawab materi yang lalu. b) Inti : guru menjelaskan penyesuaian hewan dengan lingkungannya, guru memberi tugas ( retirasi ) kepada siswa untuk mengamati penyesuaian hewan terhadap lingkungannya, guru meyuruh siswa duduk dengan kelompoknya, siswa mendiskusikan tugas yang telah dikerjakan dalam kelompoknya, anggota kelompok membacakan hasil diskusi di depan kelas, kelompok lain menanggapi hasil diskusi kelompok lain. c) Penutup : guru dan siswa menyimpulkan bersama-sama materi pelajaran, evaluasi, guru memberi PR.

3. Analisis hasil pengamatan atau observasi 
Tahap observasi dalam penelitian ini meliputi : Melakukan pengamatan terhadap siswa selama proses penelitian berlangsung, Melakukan pencatatan terhadap kejadian yang ada dalam kegiatan penelitian ini, mulai awal sampai akhir, Mengumpulkan hasil pengamatan kegiatan pembelajaran.

4. Refleksi

Pada tahap ini peneliti mengadakan refleksi pelaksanaan pembelajaran yang telah dilaksanakan.Hasil refleksi digunakan sebagai dasar untuk mengadakan penelitian dan meningkatkan mutu pendidikan.

\section{Instrument Penelitian}

Instrumen Penelitian Tindak Kelas berupa: silabus, RPP, lembar kerja siswa, ulangan, lembar pengamatan kegiatan siswa, serta lembar catatan selama pelaksanaan penelitian, lembar wawancara, catatan pelaksanaan pembelajaran.

\section{Tehnik Analisis Data}

Analisa data dilakukan secara deskriptif kualitatif berdasarkan hasil pengamatan proses dan hasil belajar, dengan langkah sebagai berikut : a) Mereduksi data, yaitu mengecek dan mencatat kembali data-data yang telah terkumpul. b) Melakukan interpretasi, yaitu menafsirkan yang diwujudkan dalam bentuk pernyataan. c) Melakukan inferensi, yaitu menyimpulkan apakah dalam pembelajaran itu terjadi peningkatan motivasi, prestasi dan hasil belajar atau tidak. d) Tahap tindak lanjut, yaitu merumuskan langkah-langkah penelitian untuk siklus berikutnya atau dalam pelaksanaan dilapangan setelah siklus berakhir. e) Pengambilan kesimpulan, diambil berdasarkan analisis hasil observasi yang disesuaikan dengan tujuan penelitian.Kemudian dituangkan ke dalam bentuk pernyataan.

\section{Pedoman Penskoran dan Kriteria Keberhasilan}

a.

$$
\text { Pedoman Penskoran }
$$

Jumlah soal adalah 10 soal, terdiri dari:

Setiap soal nilainya : 1

Skor maksimal $=100$

Pedoman penskoran adalah sebagai berikut :

Skor = Jumlah Benar X 10

b.

Kriteria Keberhasilan

Siswa dikatakan telah berhasil apabila memperoleh nilai sama atau lebih besar dari KKM yaitu 70 atau nilai baik.

\section{Analisis Dan Penyajian Data}

Data hasil kegiatan pembelajaran sebelumnya dipergunakan untuk dasar mengadakan penelitian. Adapun pelaksanaan penelitian sebagai berikut :

\section{Pelaksanaan Penelitian Pembelajaran Siklus I}

\section{Perencanaan}

Dalam perencanaan ini penulis melaksanakan sebagai berikut: merumuskan tujuan rencana penelitian kelas, membuat silabus, membuat rpp, membuat alat evaluasi, membuat lembar pengamatan, membuat lembar kerja, menyiapkan alat pembelajaran, membuat lembar catatan penelitian, membuat lembarwawancara.

\section{Pelaksanaan Penelitian}

Penelitian Tindakan Kelas siklus I dilaksanakana 2 × 35 menit, pada tanggal, 6 Oktober 2014. Pelaksanaan prebaikan siklus I sebagai berikut: a) Pembukaan (10 menit): mengcapkan salam, berdoa, mengabsen, tanya jawab materi yang lalu, guru 
menyampaikan topik pembelajaran. b) Inti ( 45 menit ) : guru menjelaskan penyesuaian hewan dengan lingkungannya, guru memberi tugas ( retirasi ) kepada siswa untuk mengamati carapenyesuaian hewan terhadap lingkungannya, guru menyuruh siswa duduk dengan kelompoknya, siswa membahas tugas yang telah dikerjakan dengan kelompoknya, anggota kelompok menanggapi hasil kerja temannya, siswa menyimpulkan hasil tanggapan terhadap tugas temanya satu kelompok. c) Penutup ( 15 menit ) : guru dan siswa menyimpulkan bersama-sama materi pelajaran, member PR

Adapun hasil ulangan penelitian siswa dapat disajikan sebagai berikut :

Tabel 4.2 Hasil UlanganPenelitian Siklus I

\begin{tabular}{|c|c|c|c|c|}
\hline \multirow[b]{2}{*}{0} & \multirow[b]{2}{*}{ Nama } & \multirow{2}{*}{ ilai } & \multicolumn{2}{|c|}{ Keterangan } \\
\hline & & & untas $^{\mathbf{T}}$ & $\begin{array}{r}\text { Bel } \\
\text { um Tuntas }\end{array}$ \\
\hline & $\mathrm{A} 1$ & $0^{5}$ & & $\mathrm{~V}$ \\
\hline & A2 & $\begin{array}{ll} & 7 \\
0 & \\
\end{array}$ & V & \\
\hline & A3 & $0^{6}$ & & V \\
\hline & A4 & $\begin{array}{ll} & 7 \\
0 & \end{array}$ & V & \\
\hline & A5 & $0^{7}$ & V & \\
\hline & A6 & $\begin{array}{ll} & 6 \\
0 & \end{array}$ & & V \\
\hline & A7 & $\begin{array}{ll} & 7 \\
0\end{array}$ & V & \\
\hline & A8 & $\begin{array}{ll} & 8 \\
0 & \end{array}$ & V & \\
\hline & A9 & $0^{5}$ & & V \\
\hline 0 & A10 & $0^{6}$ & & V \\
\hline 1 & A11 & $\begin{array}{ll} & 7 \\
0 & \\
\end{array}$ & V & \\
\hline 2 & A12 & $0^{7}$ & V & \\
\hline 3 & A13 & $\begin{array}{ll} & 8 \\
0\end{array}$ & V & \\
\hline 4 & A14 & $0^{6}$ & & V \\
\hline 5 & A15 & $\begin{array}{ll} & 7 \\
0 & \\
\end{array}$ & V & \\
\hline 6 & A16 & $0^{6}$ & & V \\
\hline 7 & A17 & $0^{6}$ & & $v$ \\
\hline 8 & A18 & $\begin{array}{ll}6 & 6 \\
0\end{array}$ & & V \\
\hline 9 & A19 & $\begin{array}{ll} & 8 \\
0 & \end{array}$ & V & \\
\hline 0 & A20 & $\begin{array}{ll} & 8 \\
0 & \end{array}$ & V & \\
\hline 1 & A21 & $0^{6}$ & & V \\
\hline 2 & A22 & $\begin{array}{ll} & 7 \\
0 & \end{array}$ & V & \\
\hline & A23 & 7 & $\mathrm{~V}$ & \\
\hline
\end{tabular}




\begin{tabular}{|c|c|c|c|c|}
\hline 3 & & 0 & & \\
\hline \multicolumn{2}{|r|}{ Jumlah } & $.530^{1}$ & $\begin{array}{ll} & 1 \\
0 & \end{array}$ & 13 \\
\hline & Rata-rata Kelas & $6,52^{6}$ & & \\
\hline & Persentase Ketuntasan Kelas & $6,52 \%$ & & \\
\hline
\end{tabular}

Berdasarkan tabel hasil ulangan dapat dipresentasikan sebagai berikut : Siswa yang memperoleh nilai lebih kecil dari KKM atau < 70 ada 10 siwa atau 43,48\% dari 23 siswa. Siswa yang memperoleh nilai sama atu lebih besar dari KKM atau $\geq 70$ ada 13 siswa atau 56,52\% dari 23 siswa. Rata-rata ulangan siklus I 55,62.

\section{HASIL dan PEMBAHASAN \\ Analisis hasil pengamatan atau observasi}

Hasil pengamatan selama kegiatan belajar mengajar berlangsung sebagai berikut : ada 4 siswa pada waktu guru menjelaskan ramai sendiri, pada waktu siswa mendapat tugas mengamati penyesuaian hewan terhadap lingkungannya ada 7 siswa sambil bermain, ada 5 siswa yang kurang aktif pada waktu membahas hasil pengamatannya dalam kelompoknya, menanggapi kerja kelompok ada 6 anak yang tidak menanggapi, ada 8 siswa kesulitan menyimpulkan hasil pengamatannya.

\section{Refleksi}

Berdasrkan hasil ulangan Penelitian dan pelaksanaan pembelajaran peneliti mengadakan refleksi sebagai berikut : guru dalam menjelaskan terlalu cepat penyesuaian hewan dengan lingkungannya terlalu cepat, pada waktu siswa mengamati penyesuaian hewan dengan lingkungannya lokasinya tidak dibatasi sehingga guru sulit memantau, pada waktu siswa membahas hasil pengamatan dengan kelompoknya guru kurang memperhatikan sehingga suasana kelas ramai, guru kurang membimbing siswa pada waktu menyimpulkan hasil pengamatnnya.

\section{Pelaksanaan Penelitian Pembelajaran Siklus II}

\section{Perencanaan}

Dalam perencanaan ini penulis melaksanakan sebagai berikut : merumuskan tujuan rencana penelitian kelas. Adapun tujuan penelitian siklus II sebagai berikut : mengaktifkan siswa dalam menyimak penjelaskan guru tentang penyesuaian hewan dengan lingkungannya. terlalu cepat, agar siswa lebih aktif dan efektif lokasinya ditentukan guru, meningkatkan peran serta siswa dalam kelompok, meningkatkan kemampuan siswa dalam menyimpulkan hasil pengamatan. Membuat silabus, membuat rpp, membuat alat evaluasi, membuat lembar pengamatan, membuat lembar kerja, menyiapkan alat pembelajaran, membuat lembar catatan penelitian, membuat lembar wawancara.

\section{Pelaksanaan Penelitian}

Penelitian Tindakan Kelas siklus II 2 × 35 menit, pada tanggal, 13 Oktober 2014 . Pelaksanaan prebaikan siklus II sebagai berikut : a) Pembukaan ( 10 menit ) : mengcapkan salam, berdoa, mengabsen, tanya jawab materi yang lalu, guru menyampaikan topik pembelajaran. b) Inti ( 45 menit ) : guru menjelaskan penyesuaian hewan dengan lingkungannya, guru memberi tugas ( retirasi ) kepada siswa untuk mengamati cara penyesuaian hewan terhadap lingkungannya, guru menyuruh siswa duduk dengan kelompoknya, siswa mendiskusikanhasil pengamatannya dikelompoknya, anggota kelompok memilih salah satu hasil pengamatan dibaca di depan kelas, siswa menanggapi hasil kerja kelompok lain, siswa menyimpulkan hasil diskusi. c) Penutup ( 15 menit ) guru dan siswa menyimpulkan bersama-sama materi pelajaran. guru memberi PR.

Adapun hasil ulangan Penelitian siswa dapat disajikan sebagai berikut Tabel 4.2 Hasil UlanganPenelitian Siklus II 


\begin{tabular}{|c|c|c|c|c|c|}
\hline \multirow[b]{2}{*}{0} & \multirow[b]{2}{*}{ Nama } & \multirow{2}{*}{\multicolumn{2}{|c|}{ ilai $^{\mathrm{N}}$}} & \multicolumn{2}{|c|}{ Keterangan } \\
\hline & & & & $\begin{array}{l}\text { Tunt } \\
\text { as }\end{array}$ & $\begin{array}{l}\text { Belum } \\
\text { Tuntas }\end{array}$ \\
\hline & $\mathrm{A} 1$ & 0 & 6 & & V \\
\hline & A2 & 0 & 7 & V & \\
\hline & A3 & 0 & 7 & V & \\
\hline & A4 & 0 & 8 & V & \\
\hline & A5 & 0 & 7 & V & \\
\hline & A6 & 0 & 7 & V & \\
\hline & A7 & 0 & 8 & V & \\
\hline & A8 & 0 & 8 & V & \\
\hline & A9 & 0 & 7 & V & \\
\hline 0 & A10 & 0 & 7 & V & \\
\hline 1 & A11 & 0 & 8 & V & \\
\hline 2 & $\mathrm{~A} 12$ & 0 & 7 & V & \\
\hline 3 & A13 & 0 & 8 & V & \\
\hline 4 & A14 & 0 & 7 & V & \\
\hline 5 & A15 & 0 & 7 & V & \\
\hline 6 & A16 & 0 & 7 & V & \\
\hline 7 & A17 & 0 & 7 & V & \\
\hline 8 & A18 & 0 & 7 & V & \\
\hline 9 & A19 & 0 & 8 & V & \\
\hline 0 & A20 & 0 & 8 & V & \\
\hline 1 & A21 & 0 & 7 & V & \\
\hline 2 & A22 & 0 & 7 & V & \\
\hline 3 & A23 & 0 & 7 & V & \\
\hline & Jumlah & 670 & 1. & 22 & 1 \\
\hline & Rata-rata Kelas & 2,60 & 7 & & \\
\hline & $\begin{array}{l}\text { Persentase Ketuntasan } \\
\text { Kelas }\end{array}$ & $5,65 \%$ & 9 & & \\
\hline
\end{tabular}

Berdasarkan tabel hasil ulangan dapat dipresentasikan sebagai berikut : Siswa yang memperoleh nilai lebih kecil dari KKM atau < 70 ada 1 siwa atau 4,35\% 
dari 23 siswa. Siswa yang memperoleh nilai sama atu lebih besar dari KKM atau $\geq 70$ ada 22 siswa atau 95,65\% dari 23 siswa. Rata-rata ulangan siklus II72,60.

\section{Analisis hasil pengamatan atau observasi}

Hasil pengamatan selama kegiatan belajar mengajar berlangsung sebagai berikut : pada waktu guru menjelaskan siswa mendengarkan, pada waktu siswa mendapat tugas mengamati penyesuaian hewan terhadap lingkungannya semua aktif, semua aktif pada waktu membahas hasil pengamatannya dalam kelompoknya, aktif menanggapi kerja kelompok, ada 1 siswa yang mengalami kesulitan menyimpulkan hasil pengamatannya.

\section{Refleksi}

Berdasrkan hasil ulangan dan pelaksanaan pembelajaran peneliti mengadakan refleksi sebagai berikut : nilai ulangan siswa mengalami peningkatan, siswa aktif mengamati penyesuaian hewan dengan lingkungannya, diskusi berjalan lancar, siswa lancar pada waktu menyimpulkan hasil pengamatnnya.tetapi masih ada 1 siswa yang mengalami kesulitan. Hasil refleksi digunakan sebagai dasar untuk meningkatkanproses belajar mengajar dan mutu pendidikan.

\subsection{Pembahasan}

Berdasarkan hasil ulangan dan pengamatan siklus I dan Siklus II menunjukkan bahwa metode retirasi meningkatkan prestasi belajar materi penyesuaian hewan dengan lingkungannya dan keaktifan siswa. Hal ini dapat dilihat sebagai berikut : Siswa yang memperoleh nilai lebih kecil dari KKM atau < 70 siklus lada 10 siwa atau $43,48 \%$ dari 23 siswa, siklus II nilai lebih kecil dari KKM atau < 70 ada 1 siwa atau 4,35\% dari 23 siswa. Siswa yang memperoleh nilai sama atau lebih besar dari KKM atau $\geq 70$ siklus lada 13 siswa atau 56,52\% dari 23 siswa,siklus II memperoleh nilai sama atau lebih besar dari KKM atau $\geq 70$ ada 22 siswa atau 95,65\% dari 23 siswa.Rata-rata ulangan siklus | 55,62, siklus || 72,60. Metode resitasi dapat meninkatkan prestasi belajar karena suatu metode mengajar dimana siswa diharuskan membuat resume dengan kalimat sendiri. Kelebihan metode resitasi sebagai berikut : Pengetahuan yang siswa didik peroleh dari hasil belajar sendiri akan dapat diingat lebih lama, Siswa didik berkesempatan memupuk perkembangan dan keberanian mengambil inisiatif, bertanggung jawab dan berdikari sendiri

\section{KESIMPULAN}

Berdasarkan hasil ulangan dan pengamatan dapat disimpulkan bahwa penerapan metode resitasidapatmeningkatkan prestasi belajar mata pelajaran IImu Pengetahuan Alam (IPA) siswa kelas V 2 Joho Kecamatan Pule Kabupaten Trenggalek semester I tahun pelajaran 2014 / 2015. Ditunjukkan dari penelitian pembelajaran pada siklus I tingkat keberhasilan ketuntasan kelas sebesar $56,52 \%$. Sedangkan pada siklus II keberhasilan ketuntasan kelas sebesar 95,65\%. Berdasarkan hasil analisis ketuntasan kelas mengalami peningkatan sebesar39.13\% dari 23 siswa.Siswa yang memperoleh nilai lebih kecil dari KKM atau $<70$ siklus I ada 10 siwa atau $43,48 \%$ dari 23 siswa, siklus II nilai lebih kecil dari KKM atau $<70$ ada 1 siwa atau $4,35 \%$ dari 23 siswa. Siswa yang memperoleh nilai sama atau lebih besar dari KKM atau $\geq 70$ siklus I ada 13 siswa atau $56,52 \%$ dari 23 siswa,siklus II memperoleh nilai sama atau lebih besar dari KKM atau $\geq 70$ ada 22 siswa atau 95,65\% dari 23 siswa.Rata-rata ulangan penelitian siklus I 55,62, siklus II 72,60. 


\section{DAFTAR RUJUKAN}

Arikunto, Suharsimi. (2011). Prosedur Penelitian: Suatu Pendekatan Praktik. Edisi.

Revisi VII. Jakarta: PT. Rineka Cipta.

Arsyad, Azhar. (2009). Media Pembelajaran. Jakarta: Rajawali Press

Djamarah, Syaiful Bahri. 1994. Prestasi Belajar dan kompetensi Guru. Surabaya: Usaha Nasional.

Hobri. 2007. Penelitian Tindakan Kelas. Jakarta: Word Press

Sanjaya, Wina. 2011. Strategi Pembelajaran Berorientasi Standart Proses Pendidikan. Jakarta: Kencana Prenada Media

Slameto. 2003. Belajar dan Faktor-Faktor yang Mempengaruhinya. Jakarta: Rineka Cipta.

Sudjana, Nana. 2010. Penelitian Hasil Proses Belajar Mengajar.Bandung: PT. Remaja Rosda Karya

Wahab, Abdul Azis. 2008. Metode dan Model-Model Mengajar. Bandung: PT. Alfabeta 